\title{
PERAN AKTOR DALAM MEDIA MASSA TERHADAP KONFLIK LAHAN KEHUTANAN ANTARA MASYARAKAT DENGAN PEMERINTAH DI MALUKU UTARA
}

\author{
Muhammad Julham ${ }^{1 \text { ] }}$ \\ ${ }^{1}$ Fakultas Pertanian dan Kehutanan, Universitas Nuku, Tidore. Indonesia. \\ Email : muhammadjulham@gmail.com
}

\author{
УInfo Artikel: \\ Diterima : 28 Mei 2018 \\ Disetujui : 15 Juni 2018 \\ Dipublikasi : 27 Juli 2018 \\ Artikel Penelitian \\ Keyword: \\ Peran Aktor, Media Massa, Konflik \\ Lahan Kehutanan \\ Korespondensi: \\ Muhammad Julham \\ Universitas Nuku, Tidore. Indonesia. \\ Email: umasugi_linda@gmail.com
}

\section{(i) (9)}

AGRIKAN

\begin{abstract}
Abstrak. Tulisan ini bertujuan untuk menganalisis pandangan media massa terhadap konflik lahan serta menganalisis aktor-aktor dalam memperakukan dan memanfaatkan media massa sesuai dengan kepentingannya. Tulisan ini menggunakan gabungan pendekatan kuantitatif dan kualitatif (mixed method). Data diperoleh melalui observasi, survey, dan dokumentasi. Hasil penelitian menunjukkan Pandangan media massa terhadap konflik lahan kehutanan di Maluku Utara ialah dengan memposisikan media massa sebagai "agent of change", selain sebagai media informasi media massa juga berperan sebagai media edukasi dengan memberikan informasi-informasi pembanding, menggunakan narasumber professional yang berkompoten dalam melihat konflik lahan kehutanan serta menyajikan data-data yang diharapkan dapat membantu masyarakat dalam proses penyelesaian kasus konflik lahan kehutanan di Maluku Utara sedangkan, aktor-aktor dalam memperlakukan dan memanfaatkan media massa berdasarkan kepentingannya terkait masalah konflik lahan kehutanan di Maluku Utara berdasarkan hasil survey, observasi, dan telaah media massa (Seputar Malut dan Malut Post) dibagi menjadi 5 (lima) klasifikasi yaitu, masyarakat, pemerintah daerah, aparat penegak hukum, LSM dan Akademisi.
\end{abstract}

\section{PENDAHULUAN}

Sumber daya alam di bidang kehutanan kini masih menjadi primadona bagi sejumlah kalangan. Selain masyarakat, pemerintah bahkan para pengusaha masih menganggap hutan sebagai sumberdaya alam yang memberikan banyak keuntungan terhadap kehidupan terutama di sektor ekonomi (Marina dkk, 2011). Atas dasar itulah yang mengakibatkan benturan sering terjadi sering berujung konflik. Konflik lahan melibatkan berbagai pihak. Akan tetapi yang sering terjhadi diantaranya konflik antara masyarakat dengan masyarakat lainnya, masyarakat dengan pemerintah maupun masyarakat dengan pihak swasta (Fisher dkk, 2001).

Konsorsium Pembaharuan Agraria mencatat 450 konflik agraria terjadi di sepanjang tahun 2016. Jumlah ini meningkat dari tahun sebelumnya yang hanya terdapat 252 konflik. Konflik di wilayah agraria mencapai 1,26 juta hektare sepanjang 2016, atau meningkat hampir tiga kali lipat dibandingkan pada 2015 yakni 400.430 hektare. Sektor Kehutanan berada di peringkat dengan 450.215 hektare sedangkan ektor perkebunan menempati urutan pertama dengan 601.680 hektare sedangkan sektor infrastruktur menempati urutan ketiga dengan 35.824 hektare (Kompas, 2017). Dominasi perseteruan warga melawan perusahaan swasta terjadi tahun lalu. Bukan hanya itu, pemerintah menjadi lawan terbanyak kedua, dengan ambisi infrastrukturnya, berebut lahan dengan warga (Kemen LHK, dalam CNN Indonesia 2017).

Departemen Kehutanan (2017) merilis data konflik terjadi sepanjang tahun 2016 terdapat 342 warga menjadi korban, sebanyak 177 orang menjadi korban kriminalisasi, 66 orang mengalami kekerasan dan penganiayaan serta 13 lainnya tewas. Aktor terlibat konflik antara lain masyarakat vs korporassi (swasta) 172 kasus, masyarakat vs pemerintah 101 kasus dan konflik antar masyarakat 65 kasus. Kasus tersebut tersebar di beberapa provinsi terbesar di Indonesia, diantaranya Riau 44 kasus, Jawa Timur 43 Kasus, Jawa Barat 38 Kasus, Sumatra Utara 36 kasus, Aceh 24 kasus dan Sumatera Selatan 22 Kasus.

Meski demikian, kasus tersebut bukannya tidak terjadi di wilayah Indonesia bagian timur. Di 
Maluku Utara misalnya, kasus agraria juga banyak terjadi. Sebagai contoh : Konflik yang terjadi antara PT. Nusa Halmahera Minerals (PT. NHM) dengan warga masyarakat Kao dan Malifut di Kabupaten Halmahera Utara, terkait hak atas tanah ulayat suku Pagu Kao di wilayah Kontrak Karya tahun 1998, Konflik pertanahan Kabupaten Halmahera Timur, terjadi antara perusahaan tambang yang melakukan pembebasan lahan antara lain oleh PT. Yudistira Bumi Bakti, PT. Kemakmuran Pertiwi Tambang, dan PT. Alam Raya Abadi terkait proses serta besar ganti rugi yang menggunakan dasar keputusan bupati tentang penetapan harga tanah dan tanaman untuk pembangunan bagi kepentingan umum pada tahun 2010 (Husen, 2013).Sementara itu, saat ini di Maluku Utara terjadi sejumlah konflik lahan di kawasan hutan. Konflik lahan tersebut terjadi di kawasan investasi perkebunan Kelapa Genjah, Kelurahan Akelamo, Kecamatan Oba Tengah, Kota Tidore Kepulauan yang melibatkan masyarakat, pemerintah daerah dan PT. Tidore Sejahtera Bersama (Teropong Timur, 2017). Selain itu, konflik juga terjadi di lahan Pariwisata Jikomalamo yang terletak di Kelurahan Akehuda dan Takome, Kecamatan Ternate Pulau, Kota Ternate. Kedua kasus sengeketa lahan yang melibatkan masyarakat, pemerintah dan swasta (pihak ketiga) terjadi pada 2016 hingga sekarang tesebut rencanya menjadi objek pada peneletian ini (Malut Post, 2017).

Karena ruang lingkup masalah yang besar, maka konflik melibatkan berbagai kelompok pemangku kepentingan di tingkat politik yang berbeda baik dengan skla kecil maupun besar. Pemangku kepentingan ini memanfaatkan media sebagai platform untuk menyebarkan sudut pandang mereka dengan tujuan memberi pengaruh terhadap opini publik; Secara bersamaan, media membantu agregasi kepentingan dalam proses politik, menyediakan saluran untuk komunikasi dan memfasilitasi revisi tujuan bersama dan kebijakan (Curran, 2002). Sampai batas tertentu, media menjalankan fungsi ini untuk ranah publik karena menyediakan akses yang lebih terbuka ke berbagai aktor (Kleinschmit, 2012). Media massa juga memainkan peran penting dalam menengahi proses musyawarah publik dan dalam masalah dan pendapat yang berbeda (Hardt, 2004). Dalam masyarakat demokratis yang kompleks modern saat ini, media adalah salah satu sumber yang paling infomasi penting bagi individu dalam memilih dan jajak pendapat; Dengan demikian, media mencerminkan opini publik (Kleinschmit \& Krott, 2008). Media memiliki tempat yang penting baik di tingkat politik nasional maupun internasional, karena menyediakan tempat dimana para aktor yang berbeda membangun argumen mereka dengan kepentingan melegitimasi kebijakan atau keputusan mereka.

\section{METODE PENELITIAN}

Jenis penelitian yang di gunakan adalah Kuantitatif dan kualitatif. Penelitian kuantitatif adalah jenis penelitian yang dapat diartikan metode penelitian yang berlandaskan pada filsafat positivisme, digunakan untuk meneliti pada populasi dan sampel tertentu, pengumpulan data menggunakan instrumen penelitian, analisis data bersifat kuantitatif/statistik (Sugiyono, 2014 :11). Sedangkan pendekatan kualitatif merupakan jenis penelitian yang mengacu pada pendekatan deskriptif. Penelitian deskriptif adalah penelitian yang dilakukan untuk mengetahui nilai variabel mandiri, baik satu variabel atau lebih (independen) tanpa membuat perbandingan, atau menghubungkan antara variabel satu dengan variabel lain (Sugiyono 2010:11).Analisis konten (isi) merupakan salah satu metode yang khas untuk penelitian yang berhubungan dengan komunikasi yang dipandang mampu menjamin adanya cara efisien, mampu memberikan alat, serta menyediakan langkah-langkah yang bermanfaat bagi peneliti pesan media (Nunung, 2010).

Populasi dari penelitian ini adalah pihakpihak yang berkepentingan atau berkonflik di kawasan investasi perkebunan Kelapa Genjah oleh PT. Tidore Sejahtera Bersama, Kelurahan Akelamo, Kecamatan Oba Tengah Kota Tidore Kepulauan dan kawasan Pariwisata Jikomalamo Kecamatan Pulau Ternate, Kota Ternate. Kedua wilayah tersebut berada di Provinsi Maluku Utara.

Sampel dari peneltian ini tidak bisa ditentukan sebelumnya karena metode yang digunakan dalam penelitian ini adalah Snowbal Sampling. Sampel ditentukan berdasarkan informasi awal dan sampel berikutnya ditentukan berdasarkan responden sebelumnya.

Content Analysis atau Analisis isi merupakan metode yang paling sering digunakan untuk melihat kecenderungan muatan pesan tertentu dan merupakan cara yang mendalam 
untuk mempelajari perubahan sosial karena tulisan tentang masyarakat yang mencerminkan perubahan dalam nilai, kepercayaan, dan perilaku (Bruce et al, 1991). Metode ini dapat ditiru dan merupakan metode yang cocok untuk membuat kesimpulan yang spesifik dari teks menjadi beberapa bagian dalam objek penelitian
(Krippendorff, 2004). Ia juga menjelaskan kerangka dalam penelitian analisis isi melibatkan pertanyaan penelitian, jenis data, konteks yang berhubungan dengan data, dan penarikan kesimpulan dari data ke aspek tertentu tentang konteksnya.

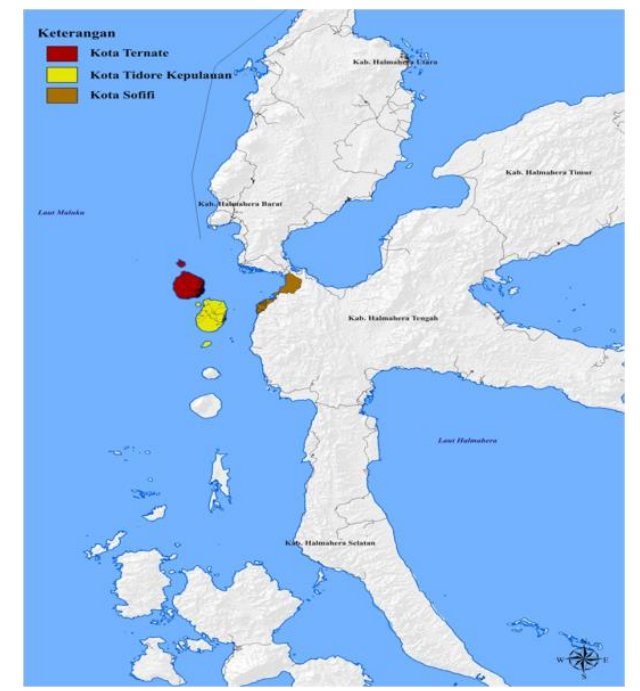

Gambar 1. Peta Orientasi Wilayah Studi Kota Ternate dan Kota Tidore Kepulauan

\section{PEMBAHASAN}

Penggunaan tanah di Provinsi Maluku Utara terbagi ke dalam 3 jenis penggunaan, yakni, kawasan hutan, peruntukan kawasan non-hutan, dan lahan pertanian pangan berkelanjutan (LP2B). Sebagian besar penggunaan tanah di Provinsi Maluku Utara didominasi oleh Kawasan Hutan yakni seluas $2.531 .134 \mathrm{Ha}$ atau mencapai $16.69 \%$. Provinsi Maluku Utara menggunakan lahan untuk pertanian berkelanjutan (LP2B), yakni sebesar $13,14 \%$ atau seluas 1.957 .799 Ha. Namun, dari peruntukan tersebut hanya $5.777 \mathrm{Ha}$ tanah yang berupa sawah beririgasi (Sumber: Profil Pertanahan Maluku Utara 2015). Pada tahun 2015, cakupan luas wilayah bidang bersertifikat yang sudah terdigitasi secara keseluruhan di Provinsi Maluku Utara mencapai 15.667,81 Ha. Kabupaten/Kota yang memiliki bidang bersertifikat di Maluku Utara hanya Kabupaten Halmahera Barat, Kota Tidore Kepulauan, dan Kabupaten Halmahera Selatan (Sumber: Profil Pertanahan Maluku Utara 2015). Selain sertifikat hak milik, Kanwil BPN Provinsi Maluku Utara juga mengeluarkan sertifikat pertanahan dalam bentuk sertifikat Hak Guna Usaha (HGU), Hak Guna Bangunan (HGB), dan Hak Pakai. Dalam periode tahun s.d 2003 hingga 2013, Hak Pakai memiliki jumlah bidang paling banyak dibanding yang lainnya dengan jumlah sebanyak 89 bidang dan luas total sebesar $175.31 \mathrm{Ha}$. Sedangkan untuk HGU, meskipun hanya 1 bidang yang tersertifikasi, namun memiliki luasan tanah yang paling luas, yakni mencapai $7.797 \mathrm{Ha}$.

Kasus pertanahan berdasarkan subyek di Provinsi Maluku Utara terjadi antara masyarakat dan pemerintah serta antar masyarakat. Sengketa antar masyarakat menjadi kasus terbanyak dengan jumlah kasus sebanyak 119 dari tahun 2006 hingga 2013. Sedangkan kasus antara masyarakat dan pemerintah hanya terjadi sebanyak 5 kasus di tahun 2007, 2008, 2010, dan 2012. Kasus Dengan jumlah terbanyak adalah kasus penguasaan tanah tanpa hak dan sertifikat pengganti dengan jumlah sebanyak 25 kasus di Provinsi Maluku Utara. Kasus sengketa batas dan kasus akta jual-beli palsu sebanyak 13 kasus. Sedangkan untuk kasus sertifikat ganda dan putusan pengadilan menjadi kasus dengan jumlah paling sedikit yang terjadi di tahun 2007 dan 2008 sebanyak 4 kasus.

Dari kasus pertanahan yang terjadi di Provinsi Maluku Utara, terdata bahwa sudah $85,85 \%$ kasus pertanahan yang sudah terselesaikan di Provinsi Maluku Utara hingga tahun 2013. Sedangkan kasus yang belum terselesaikan masih sekitar 14,15\% dari kasus pertanahan yang terjadi di provinsi tersebut. Kasus pertanahan yang belum 
terselesaikan tersebut perlu diupayakan penyelesaiannya mengingat keberadaan kasus tersebut dapat menghambat kegiatan penggunaan lahan yang optimal serta adanya potensi kasus pertanahan baru lainnya yang muncul.

Tabel 1. Jumlah Kasus Pertanahan Berdasarkan Obyek di Provinsi Tahun 2006-2013

\begin{tabular}{clc}
\hline No & \multicolumn{1}{c}{ Jenis Kasus } & Jumlah Kasus \\
\hline 1 & Tumpang Tindih & 5 \\
2 & Akta Jual Beli Palsu & 13 \\
3 & Penguasaan Tanah Tanpa Hak & 25 \\
4 & Sengketa Waris & 6 \\
5 & Putusan Pengadilan & 4 \\
6 & Kekeliruan Penunjukkan Batas & 6 \\
7 & Sengketa Batas & 13 \\
8 & Sertifikat Pengganti & 25 \\
9 & Sertifikat Ganda & 4 \\
10 & Jual Berkali Kali & 5 \\
\hline & $\quad$ Jumlah & 106 \\
\hline
\end{tabular}

Sumber: Kanwil BPN Provinsi Maluku Utara, 2014
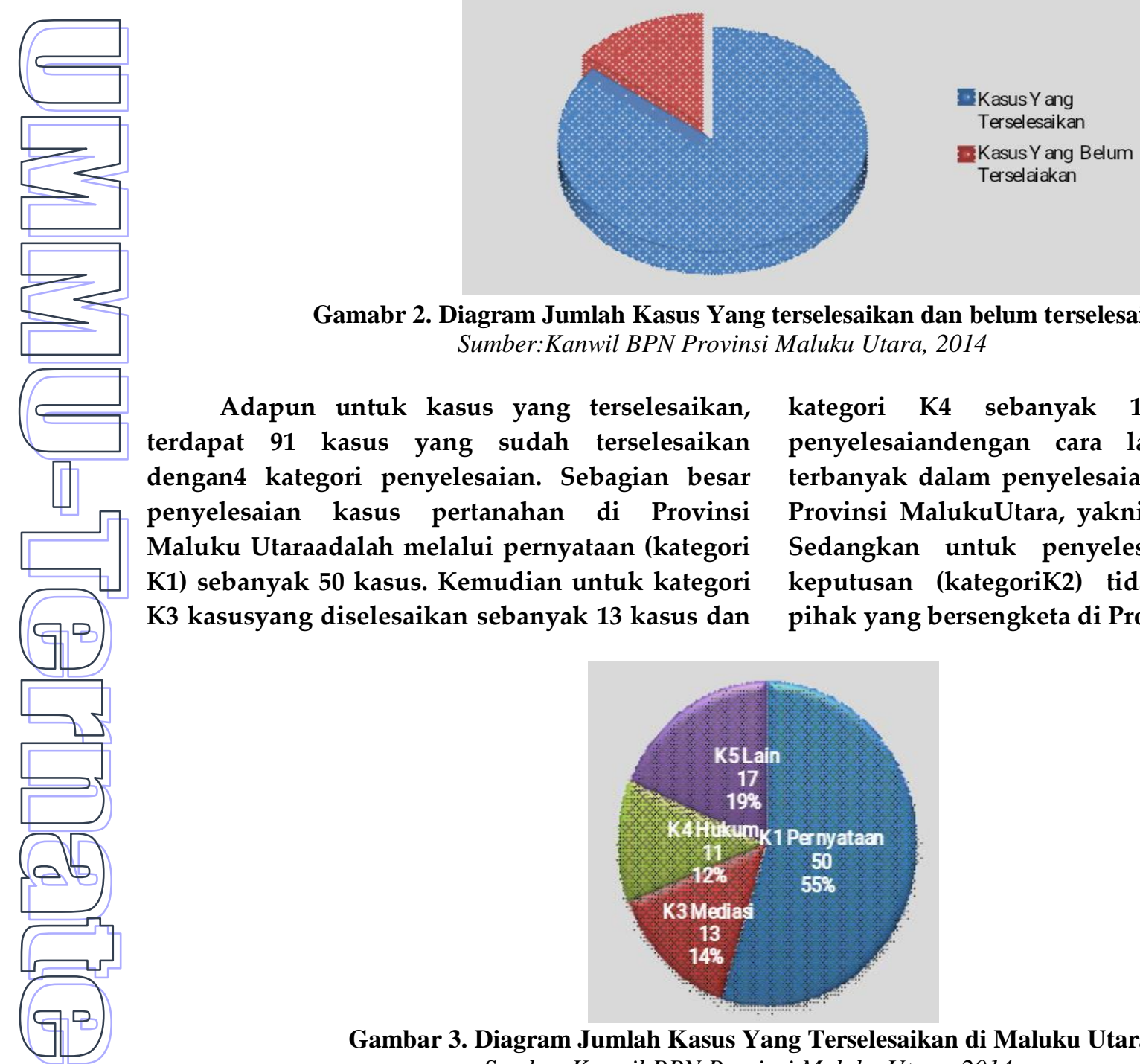

Gamabr 2. Diagram Jumlah Kasus Yang terselesaikan dan belum terselesaikan Sumber:Kanwil BPN Provinsi Maluku Utara, 2014

Adapun untuk kasus yang terselesaikan, terdapat 91 kasus yang sudah terselesaikan dengan4 kategori penyelesaian. Sebagian besar penyelesaian kasus pertanahan di Provinsi Maluku Utaraadalah melalui pernyataan (kategori K1) sebanyak 50 kasus. Kemudian untuk kategori K3 kasusyang diselesaikan sebanyak 13 kasus dan kategori K4 sebanyak 11 kasus. Adapun penyelesaiandengan cara lain menjadi kedua terbanyak dalam penyelesaian yang dilakukan di Provinsi MalukuUtara, yakni sebanyak 17 kasus. Sedangkan untuk penyelesaian dengan surat keputusan (kategoriK2) tidak digunakan oleh pihak yang bersengketa di Provinsi Maluku Utara.

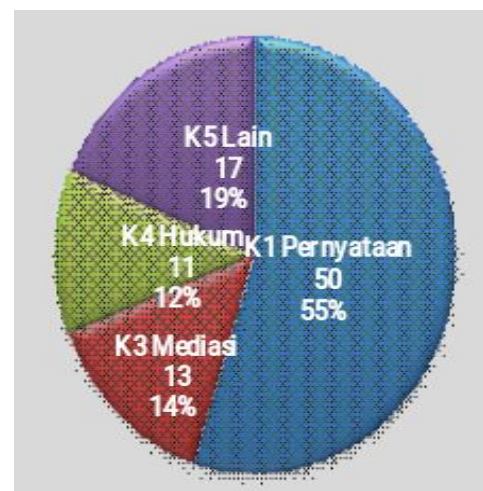

Gambar 3. Diagram Jumlah Kasus Yang Terselesaikan di Maluku Utara Sumber:Kanwil BPN Provinsi Maluku Utara, 2014 
3.1. Pandangan Media Terhadap Konflik Lahan Kehutanan di Maluku Utara (Konflik Lahan Jiko Malomo dan Akelamo)

Analisis dan Pembahasan sub bab ini bertujuan untuk menjawab rumusan masalah pertama terkait pandangan media terhadap konflik lahan kehutanan di Maluku Utara pada dua studi kasus penelitian ini yaitu kasus konflik lahan Jiko Malamo yang terjadi di Kelurahan Takome dan Kelurahan Sulamahada Kota Ternate serta kasus konflik lahan yang terjadi di Kelurahan Ake Lamo Kota Tidore Kepualauan yang disajikan oleh surat kabar Seputar Malut dan Malut post. Aspek yang dijadikan indikator dalam pembahasan terkait pandangan media terhadap konflik lahan yang terjadi pada kedua lokasi studi yakni substansi isi pemberitaan media yang seharusnya sebagai pengontrol, dan menjajikan informasi yang obyektif berkaitan dengan Media/pers sebagai komponen penting dalam struktur sosial yang berfungsi memelihara dan harmonisasi diantara komponen yang lain dalam masyarakat dengan cara menyampaikan informasi.

Intensitas pemberitaan tentang suatu peristiwa dengan tema tertentu sangat dipengaruhi oleh aktualitas dan nilai pentingnya suatu peristiwa. Perhatian media akan dengan mudah beralih ketika terjadi suatu peristiwa baru yang menjadi pusat perhatian publik. Hal ini wajar terjadi di dalam industri pers, karena pemberitaan tentang suatu peristiwa yang sedang hangat terjadi ditinjau dari sisi aktualitas akan memiliki nilai jual lebih dibandingkan dengan peristiwa yang terjadi sebelumnya. Fenomena konflik merupakan realitas sosial yang terjadi dimasyarakat, yang dimana konflik terjadi apabila tidak ada keselarasan di masyarakat,media sebagai ruang komunikasi massa memberikan warna dan informasi apa sesungguhnya sehingga konflik itu dapat terjadi hal tersebut sejalan dengan pendapat kedua Pimpinan Redaksi berdasarkan hasil wawancara peneliti dengan Pimpinan Redaksi Baik Harian Malut Post Maupun Seputar Malut. Berikut adalah kutipan hasil wawancara peneliti dengan Pimpinan Redaksi Malut Post Faisal Djlaludin yang peneliti temui pada tanggal 21 Maret 2018:

Yang paling utama bagi kami adalah menjalankan fungsi jurnalis. Kami mengabarkan sesuatu yang perlu diketaui oleh masyarakat. Dan soal jikmalamo dan akelamo adalah sebuah hal yang menarik bagi media untuk menginformasikan agar diketahui publik. Publik tahu bagaimana prosesnya, apa yang teradi dan lains sebagainya. Kami bukan sekedar mengabarkan saja, namun tugas kami adalah memberikan informasi-informasi pembandi, menyajikan data-data yang diharapkan dapat membantu masyarakat dalam proses penyelesaian kasus itu.Sementara kami yakin tidak ada yang menekan kami, baik pihak yang berkonflik maupun pihak lain sejauh kasus itu berlangsung. Hanya saja kami berupaya menjalankan kerjakerja jurnalis dengan karya-karya yang berkualitas untuk masyarakat. (Faisal Djalaludin, 2018).

Hal yang sama juga di sampaikan oleh Pimpinan Redaksi Seputar Malut Abdul Rahman yang peneliti temui pada tanggal 20 Maret, 2018. Dalam kasus Jikomalamo di Kota Ternate dan Akelamo di Kota Tidore merupakan berita kasuistik, bukan hanya sekedar perang wacana atau opini biasa. Mengingat karena ini adalah kasus yang benar-benar terjadi di lapangan maka selaku media massa kami memberitakan itu sebagaimana biasa. Dalam kepentingan pemberitaan kami telah mengunakannya sesuai dengan produk jurnalis. Ketika ada insiden, kami melakukan peliputan dan langsung memberitakan, selain itu kami tentunya melibatkan banyak pihak yang berkompeten yang bicara terkait masalah itu. Ini penting dilakukan sehingga mencari keseimbangan dalam sebuah pemberitaan. Kami tidak memiliki kepntingan soal siapa salah siapa benar, akan tetapi kepentingan kami adalah mengungkap fakta. Dalam pemberitaan kami tidak pernah ditekan atau diintimidasi oleh pihak-pihak manapun. (Abdurahman, 2018)

Apa yang disampaiakan oleh kedua pimpinan redaksi tersebut dapat di buktikan melalui beberapa isi pemberitaan yang diterbitkan baik Malut Post maupun Seputar Malut yang dengan lugas mengungkap fakta aktual yang terjadi terkait masalah konflik lahan baik konflik lahan Jiko Malamo di Kota Ternate maupun konflik Lahan Akelamo di Kota Tidore.

Berikut adalah salah satu pemberitaan yang diterbitkan oleh Harian Seputar Malut edisi Sabtu 18 Februari 2017 terkait konflik lahan Jiko Malamo. 


\section{Warga Hiri Keluhkan Pelabuhan Jikomalamo \\ (SEPUTAR MALUT)}

TERNATE-Warga pulau Hiri mengeluhkan pemindahan pelabuhan sementara dari Sulamdaha ke Jikomalamo meski kondisinya aman dari ombak dan memilik dermaga yang memadai, namun Warga mengaku kesulitan mencari angkuta umum.

Sebab, tak ada angkuta umum yang masuk hingga ke kawasan jikomalamo. "Warga banyak mengeluh, terutma Ibu- ibu yang berdagang di pasar ternate, merekakesulita mencari angkot atau ojek yang masuk sampai di wisata jikomalamo. Mereka sudah beberapa kali mengadu ke saya," Kata camat pulau Hiri Rustam, kemarin (31/10).

Salah satu contoh isi pemberitaan yang diterbitkan oleh Harian Seputar Malut terkait konflik lahan Jiko Malamo di Kota Ternate diatas merupakan bentuk informasi kepada khalayak terkait keluhan masyarakat yang mendapat imbas dari konflik lahan Jiko Malamo. Hal yang sama juga tersaji pada harian Malut Post yakni penyajian berita yang bersifat factual terkait janji Pemerintah Kota Ternate untuk memfasilitasi penyelesaian masalah konflik lahan Jiko Malamo yang tidak terealisasi berita ini diterbitkan pada edisi Senin 6 Maret 2017.

\section{Soal Jikomalamo, Pemkot Ingkar Janji}

(MALUT POST)

TERNATE- Janji manis Pemerintaj Kota Pemerintah Kota (pemkot) kepada warga Hiri hingga kini tidak terbukti. Pasalnya, saat pertemuan dengan warga Hiri yang melanggar aksi lalu dan HearingDinas Perhubungan dengan Komisi I DPRD pada pertengahan ferbruari lalu, pemkot berjanji akan mengaktifkan Pelabuhan Jikomaloma sebagai pelabuhan penyebrangan pada februaru tidak terealisasi....

Hal yang sama juga terjadi pada masalah konflik lahan Akelamo Kota Tidore Kepualauan. Peranan media melalui pemberitaan pada kedua surat kabar yakni Malut Post dan Seputar Malut dalam mengungkap fakta tanpa ada keberpihakan pada pihak manapun untuk diketahui oleh publik. hal ini dapat terlihat pada muatan pembertitaan yang di terbitkan oleh kedua surat kabar tersebut. Berikut adalah isi dari beberapa pemberitaan terkait masalah konflik lahan yang terjadi di Akelamo Kota Tidore Kepulauan baik oleh surat kabar Malut Post maupun Seputar Malut.

Isi pemberitaan Malut Post edisi Rabu, 1 November 2017.

\section{AMAN Lapor Ke Komnas HAM \\ Terkait investasi PT TSB di Kelurahan Akelamo}

(MALUT POST)

TIDORE - Status sah kepemilihan lahan keperusahaan Nasional Perkebunan (PNP) di Kelurahan Akelamo, kecamatan oba Tenah, Kota Tidore Kepulauan (Tikep), sepertinya masih sebatas klaim mengklaim. Setidaknya hanya sedikit pihak yang ragu ketika pekot Tikep mengaku tanah di kelurahan Akelamo yang kini di kuasai PT Tidore Sejaterah Bersama (TSB) itu sudah milik pemkot.Aliansi Masyarakat Adat Nusantara (AMAN) Malut adalah satu pihak yang masih ragu.

Isi pemberitaan Seputar Malut edisi4 April 2017

\section{Warga Akelamo Tuntut Ganti Rugi Ancaman Boikot Penanaman KelApa Ganjah (SEPUTAR MALUT)}

TIDORE- Baru saja dilakukan penanaman kelapa ganjah di Oba, sudah muncul protes warga. Senin (3/4) warga Akelamo yang mengklaim memiliki tanaman di areal milik Pemerintah KotaTidore Kepulauan (Tikep) yang kini ditanami kelapa ganjah itu di persoalkan. Mereka bahkan mengelar aksi di kantor Wali Kota Tikep. 
Contoh dari isi pemberitaan yang peneliti cantumkan diatas merupakan sebuah bentuk upayaMedia massa khususnya di Maluku Utara sebagai institusi yang berperan sebagai "agent of change", Dalam menjalangkan paradigma media meliputi beberapa poin diantaranya:

- Sebagai Institusi percerahan masyarakat, yang diamana peranya sebagai media edukasi. Media massa menjadi media yang setiap saat mendidik masyarkat supuya cerdas, terbuka pikiranya, dan menjadi masyarakat maju.

- Sebagai media informasi, yang dimana setiap saat menyampaikan informasi kepada masyarakat. Dengan harapan masyarakat akan mengarah pada masyarakat informatif.

3.2 Aktor-Aktor dalam Memperlakukan dan Memanfaatkan Media Massa Berdasarkan Kepentingannya.

Aktor-aktor dalam memperlakukan dan memanfaatkan media massa berdasarkan kepentingannya terkait masalah konflik lahan kehutanan di Maluku Utara berdasarkan hasil survey, observasi, dan telaah media massa (Seputar Malut dan Malut Post) dibagi menjadi 5 (lima) klasifikasi yaitu,

a. Pihak masyarakat yang terlibat konflik lahan cenderung memanfaatkan media massa sebagai alat dalam memperjuangkan hak hak mereka atas lahan yang mereka kuasai. Hal ini di tunjukkan oleh masyarakat Akelamo dalam menuntut hak ganti rugi atas lahan yang dikuasai oleh pemerintah Kota Tidore Kepulauan.

b. Pemerintah Daerah, terjadi perbedaan peran pemerintah daerah dalam memperlekukan dan memanfaatkan media massa dimana, pemerintah Kota Ternate cenderung memanfaatkan media massa untuk menyelesaikan konflik dengan berperan sebagai mediator dalam konflik lahan yang terjadi di Jiko Malamo, sedangkan Pemerintah Kota Tidore Kepulauan berperan sebagai pihak yang seakan tidak bersalah dalam konflik lahan yang terjadi di Akelamo dalam pemperlakukan dan memanfaatkan media. c. Aparat Penegak Hukum berperan sebagai pihak penegak hukum yang serius terlibat dalam menangani masalah konflik lahan yang terjadi baik itu konflik lahan Jiko Malamo maupun konflik lahan akelamo dalam memperlakukan dan memanfaatkan media massa.

d. Lembaga Swadaya Masyarakat (LSM) berperan sebagai pihak yang selalu hadir dalam membela hak hak masyarakat yang terkena dampak konflik lahan dalam memperlakukan dan memanfaatkan media massa

e. Akademisi berperan sebagai pihak professional yang selalu mengedepandan unsur edukasi dalam melihat masalah konflik lahan yang terjadi dengan memanfaatkan dan memperlakukan media massa.

\section{PENUTUP}

Berangkat dari tujuan tulisan ini dan sesuai dengan hasil pembahasan, maka dapat disimpulkan bahwa Pandangan media massa terhadap konflik lahan kehutanan di Maluku Utara ialah dengan memposisikan media massa sebagai "agent of change", selain sebagai media informasi media massa juga berperan sebagai media edukasidengan memberikan informasiinformasi pembanding, menggunakan narasumber professional yang berkompoten dalam melihat konflik lahan kehutanan serta menyajikan datadata yang diharapkan dapat membantu masyarakat dalam proses penyelesaian kasus konflik lahan kehutanan di Maluku Utara. Dari hasil survey dan observasi maupun telaah isi surat kabar baik Malut Post Maupun Seputar Malut terkait masalah konflik lahan Baik itu Konflik Lahan Jiko Malamo di Kota Ternate dan konflik lahan Akelamo di Kota Tidore Kepulauan peneliti mengklasifikasikan aktor aktor yang terlibat di dalamnya secara umum menjadi 5 (empat) kalsifikasi yaitu; Masyarakat yang memiliki kepentingan atas lahan konflik, Pemerintah Daerah, Aparat Penegak Hukum Lembaga Swadaya Masyarakat (LSM) dan Akademisi

\section{REFERENCES}

Alex Sobur, 2001. AnalisisTeks Media: SuatuPengantaruntukAnalisisWacana, AnalisisSemiotik, danAnalisis Framing. Rosda: Bandung.

BAPPELITBANG Kota TidoreKepulauan. Rencana Pembangunan JangkaMenegah Daerah (RPJMD) 2016-2020. 
BPS Kota Ternate. Kota Ternate DalamAngka 2017.

Bruce A. Chadwick, Howard M.Bahr\& Stan L. Albrecht. 1991. Pengetahuan Sosial. Semarang: IKIP Semarang Press.

Burhan Bungin. 2008. Sosiologi Komunikasi: Teori, Paradigma, dan diskursus teknologi komunikasi di masyarkat. Jakarta, Kencana,2008

Curran, J. 2002. Media and power. London/New York: Routledge.

Direktorat Tata Ruang dan Pertanahan. Profil Pertanahan Provinsi Maluku Utara 2015

Hardt, F. 2004. Mapping the world: New perspectives in the humanities and social sciences. Tübingen: Francke Verlag.

Dewan Perwakilan Rakyat Republik Indonesia.1999.UU No. 411999 Tentang Kehutanan. Jakrta: Dewan Perwakilan Rakyat Republik Indonesia.

Fisher, S, D. I. Abdi, J. Ludin, R. Smith, dan S. Williams. 2000. Mengelola Konflik: Keterampilan dan Strategi untuk Bertindak. Kartikasari, S. N, M. D. Lapilatu, R. Maharani dan D. N. Rini [Penterjemah]. The British Council. Jakarta.

Fuad, Faisal dan Siti Maskanah. 2000. Inovasi Penyelesaian Sengketa Pengelolaan Sumber Daya Hutan. Pustaka LATIN. Bogor.

H. HafiedCangara. 2006. PengantarIlmuKomunikasi. PT. Raja Grafindo.

Hae, Nur Zain, RusdiMarpaung, HaweSetiawan. 2000. Konflik Multikultur Panduan Meliput bagi Jurnalis. Lembaga studi Persdan Pembangunan (LSPP). Didukung oleh The Asia Foundation dan USAID. Jakarta.

Hendricks, William. 2004. Bagaimana Mengelola Konflik, Petunjuk Praktis Untuk Manajemen Konflik yang Efektif. Penerjemah Arif Santoso. How to Managemen Conflict. Cet. V. PT. BumiAksara. Jakarta.

HusenAlting. 2013. Jurnal: KonflikPenguasaan Tanah di Maluku Utara: Rakyat Versus PenguasadanPengusaha. UniversitasKhairun, Ternate.

Ibrahim, Jabal Tarik. 2002. SosiologiPedesaan. UMM Pres. Malang.

Kleinschmit, D. (2012). Confronting the demands of a deliberative public sphere with media constraints. Forest Polica and Economic, 16,7180.

Krippendorff.2004.Content Analysis: An Introductions to its Methodology, second edition. California: Sage Publication.

KurniawanEko. 2006. Studi Analisis Isi Pemberitaan Media Massa Tentang Lingkungan Hidup Dan Implikasinya TerhadapKebijakanPengelolaanLingkungan Di Kabupaten Bangka. Tesis Dipublikasi. Program magister ilmu lingkungan Program pascasarjana Universitas diponegoro. Semarang.

M.A. Safitri. 2012. Pengelolaan Hutan Berbasis Masyarakat, Konflik Kehutanan dan Keadilan Tenurial: Peluang dan Limitasi, diambil dari: file://C:/ Users/julham/Downloads/Documents/Pengelolaan_Hutan_Berbasis_Masyarakat_Ko_4.pdf: diaksestanggal 7 November 2017.

Maftuh, Bunyamin. (2008). Pendidikan Resolusi Konflik. Bandung : CV Yasindo Multi Aspek.

Mitchell, Bruce, B. Setiawan, Dwita H. Rahmi. 2000. Pengelolaan Sumberdaya dan Lingkungan. Gadjah Mada University Press. Yogyakarta.

Nunung, Prajarto. 2010. Analisis Isi: Metode Penelitian Komunikasi. Yogyakarta: FISIPOL UGM.

Saputra, Farid. 2011. Artikel: Konflik dan Media Massa. http://prafuconections.blogspot.co.id/2011/11/ konflik-dan-media-massa.html: diakses 8 November 2017.

Sugiyono. 2013. Metode Penelitiaan Kuantitatif Kualitatif dan RED. Alfabeta. Bandung. 